\title{
Pensononowoor
}

2015 , vol. $73,55-64$

http://dx.doi.org/10.12657/denbio.073.006

\author{
Artur Serafin, Magdalena Pogorzelec, Barbara Banach, \\ Jacek Mielniczuk
}

\section{Habitat conditions of the endangered species Salix myrtilloides in Eastern Poland}

Received: 17 January 2014; Accepted: 5 November 2014

\begin{abstract}
Changes in habitat conditions in the area of Eastern Poland (Polesie Podlaskie), often associated with anthropopressure, cause a reduction in the number of locations and population size of valuable and rare bog plant species, including a Pleistocene boreal relict, Salix myrtilloides. The aim of this study was to determine the current conditions of occurrence of this species based on the physico-chemical parameters of peatland piezometric groundwater. The results confirm the declining trend in the number of locations and abundance of this species in the past few decades, but at the same time they confirm the wide range of amplitude of the many investigated factors. Among the groundwater parameters studied, the low level of nitrogen fractions, phosphorus fractions, cations, and DOC can be considered to be a set of conditions promoting the preservation of the Salix myrtilloides population. The higher concentrations of phosphates, sulfates, $\mathrm{Na}, \mathrm{Ca}$, and $\mathrm{Mg}$ as well as higher $\mathrm{pH}$ and electrolytic conductivity can be considered to be presumably unfavorable. The lack of significant differences in the values of the piezometric water factors investigated for the sites with different population sizes of the studied species requires the identification of other limiting factors and the implementation of programs for its active protection in Poland.
\end{abstract}

Additional key words: boreal relict, physico-chemical factors, positive zone, ecological succession

Addresses: A. Serafin, M. Pogorzelec, B. Banach, Department of General Ecology, University of Life Sciences in Lublin, Akademicka 13, 20-950 Lublin, Poland, e-mail: artur.serafin@up.lublin.pl J. Mielniczuk, Department of Experimental Theory and Biometrics, University of Life Sciences in Lublin ul. Akademicka 13, 20-950 Lublin, Poland

\section{Introduction}

As a result of the geobotanical location of Poland, its peatland flora is characterized by a variety of range units, including typical continental species, oceanic-continental taxa and species of northern continental affiliation.

Due to the significant amplitudes of $\mathrm{pH}$ and trophic status of peatland habitats, which results from the type of hydrological supply in these habitats, the phytocenoses associated with a particular ecological peat bog type have their own distinctive species composition. Besides, as a result of the specific habitat conditions of a particular peat bog itself, the flora of such an ecosystem is characterized by a high proportion of species with a narrow or extremely narrow range of ecological tolerance, despite the numerous morphological, anatomical, physiological and ecolog- 
ical adaptations that enable them to survive in often extreme environmental conditions (Fijałkowski 1991; Kłosowski and Kłosowski 2001; Ilnicki 2002; Tobolski 2003).

Thus, peatland flora plays a considerable role in determining the biodiversity, especially in Eastern Poland, where there are peatlands with relatively large areas and a high level of naturalness. Among the plants associated with the influence of the northern continental climate and having specific habitat requirements, special attention should be paid to rare and protected Pleistocene boreal relicts, such as Betula humilis, Salix lapponum or Salix myrtilloides (Fijałkowski 1991; Kruszelnicki et al. 2001; Churski and Danielewicz 2008; Pogorzelec 2008, 2009).

As a result of the limited availability of suitable habitats and their isolation, the possibility of occurrence and dispersion of boreal relicts is very low. Therefore, there is a real threat of extinction of local populations of these species (Churski and Danielewicz 2008).

Natural or anthropogenically induced changes in habitat conditions resulting in the acceleration of the rate of ecological succession in peat bogs significantly increase the possibility of occurrence of the effects adverse to species biodiversity. This is reflected in Eastern Poland (Polesie Podlaskie which includes the Łęczna-Włodawa Lake District) where since the late 1970's we have observed more and more factors that negatively influence the natural state of the lake and peatland ecosystems. Anthropogenic impact, e.g. the pressure from agriculture, tourism, operations in the Lublin Coal Basin activity, and the Wieprz-Krzna Channel system, has led to a decrease in water surface levels, the acceleration of water drainage, and an increase in the supply of nutrients, which has changed the physiognomy of the landscape and habitat conditions of many natural ecosystems in Polesie. These processes have resulted in fragmentation and biocenotic changes in habitats (Serafin 2009; Serafin and Pogorzelec 2011).

This poses a special threat to valuable and rare boreal relicts, among them Salix myrtilloides which is critically endangered with extinction (Polish Red Book of Plants, Red List of Plants and Fungi of Poland) and is not able to compensate for the negative impact of anthropopressure. This species is threatened mainly due to the expansion of forest vegetation, peat mining, and progressive eutrophication of habitats. Its ease of interbreeding with other willow species and the displacement of pure forms by hybrids can also be a source of threat (Piękoś-Mirkowa 2003).

The aim of this study was to determine the amplitude of selected habitat factors representing the current conditions of occurrence of Salix myrtilloides in Eastern Poland (Polesie Podlaskie region). S. myr- tilloides of the family Salicaceae Mirb. is a subarctic boreal species of circumpolar range. As a glacial relict, in Poland it has the status of endangered species (category-EN) or critically endangered species (category - CE). If these threat factors do not disappear, this species will become extinct in the near future (Kruszelnicki et al. 2001; Mirek et al. 2006; Churski and Danielewicz 2008).

The obtained information will expand the knowledge of the probable causes of the withdrawal of this species' populations from their natural locations. It will also be used to develop a program for active protection of this species and to indicate the sites of possible reintroduction of the species within the study area.

\section{Methods}

The study was conducted in Eastern Poland, in the region of Polesie Podlaskie, in every stand of the $S$. myrtilloides populations in the peat bogs on Lake Bikcze, Lake Moszne, and Dekowina, as confirmed in the pilot research.

The first stage of the study was to determine the exact number of $S$. myrtilloides individuals (an individual was considered to be each aboveground shoot, regardless of underground connections).

The exact location of the studied population was determined using a portable GPS device (Garmin Oregon 550t). The coordinates were determined for the central part of the stand where the population occurred (according to Churski and Danielewicz 2008). In those locations, soil piezometers (a $1 \mathrm{~m}$ perforated PVC pipe with a diameter of $100 \mathrm{~mm}$ ) were installed: Bikcze (B): N51 22.771 'E02302.588' (the population consisted of 107 S. myrtilloides individuals), Moszne (M): N51 27.612 'E02307.251' (241 individuals), Dekowina (D): N51²6.689 'E02331.368’ (120 individuals) (Fig. 1).

In the period 2011-2013, peat bog water $\left(1 \mathrm{dm}^{3}\right)$ was collected from the soil piezometers for laboratory analysis. Every year, the water was sampled at three times, one per season: spring, summer, and autumn (9 times in total).

The laboratory analyses, carried out at the Central Agroecological Laboratory (CLA) of the University of Life Sciences in Lublin using generally accepted certified methods, determined the basic physico-chemical factors in the piezometric water. The following habitat factors were examined: electrolytic conductivity, $\mathrm{pH}$ and dissolved organic carbon (DOC), as well as selected chemical parameters determining plant growth and condition - nitrogen fractions: total nitrogen $\left(\mathrm{N}_{\text {total }}\right)$, ammonium nitrogen $\left(\mathrm{N}-\mathrm{NH}_{4}\right)$, nitrates $\left(\mathrm{N}-\mathrm{NO}_{3}\right)$, nitrites $\left(\mathrm{N}-\mathrm{NO}_{2}\right)$; phosphorus fractions: phosphorus $\left(\mathrm{P}_{\text {total }}\right)$, phosphate (P- 


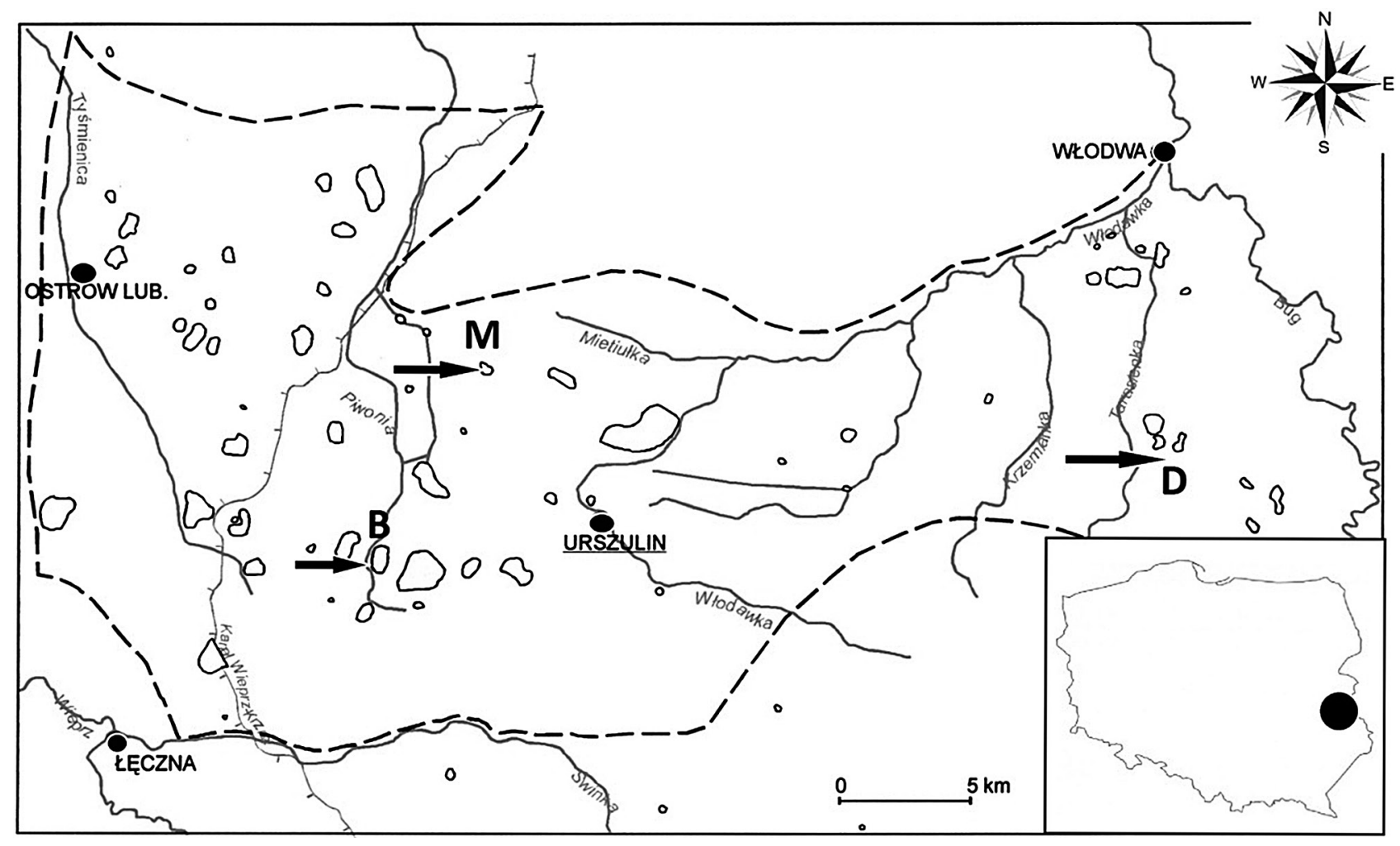

Fig. 1. Location of study sites of the S. myrtilloides population in Polesie Podlaskie (Eastern Poland) B - Bikcze, M - Moszne, D - Dekowina

$\left.\mathrm{PO}_{4}\right)$; sulfates $\left(\mathrm{S}_{-} \mathrm{SO}_{4}\right)$; and basic cations: potassium $(\mathrm{K})$, sodium $(\mathrm{Na})$, calcium $(\mathrm{Ca})$, magnesium $(\mathrm{Mg})$.

The results were analyzed in terms of the range of values of the investigated factors of the studied species in relation to the individual study sites (B, $\mathrm{M}, \mathrm{D})$ and the total (+ BMD) as well as statistical relationships were determined.

Due to the lack of normality of distribution and the heterogeneity of variance across multiple data sets of the parameters, it was impossible to use the classical statistical analysis ANOVA. Therefore, in order to compare the distributions of the factors in the particular habitats, the nonparametric Kruskal-Wallis test was employed. Post-hoc analysis was done by running a set of Mann-Whitney tests with Bonferroni correction to adjust the $\mathrm{p}$-values for multiple comparisons.

The ranges of the studied habitat factors, which includes statistical testing, are shown graphically in the form of boxed charts presenting the specific characteristics of empirical distributions according to the following specifications.

The distribution of observations is shown in the box-and-whisker plots. The bottom and top of the box designate the first and the third quartiles, respectively. Thus, the inter-quartile range (IQR) corresponds to the high of the box. The horizontal line across the central region of the box characterizes the median. The mean value of the data is marked by a filled square. Two vertical dashed lines, called whiskers, extend from the bottom and top of the box. The whiskers are drawn to the most extreme observations that are located no more than 1.5 times the IQR away from the box. Any observation not included between the whiskers is considered as an outlier and plotted with an open circle. When there are no outliers, the whiskers indicate the minimum and maximum values. The following abbreviations are used for labeling tick marks on the $\mathrm{x}$-horizontal axis: B - Bikcze, M - Moszne, D - Dekowina. The x axis label provides the p-value derived by the Kruskal-Wallis test.

Detrended correspondence analysis (DCA) and principal component analysis (PCA) were applied to reveal principal variation patterns within the data. Ordination analyses included the three study sites and 14 environmental variables (physico-chemical factors).

We used R 3.0.2 software (R Core Team 2013) for all statistical analyses and the vegan package 2.0-8 (Oksanen et al. 2013) for multivariate investigations.

\section{Results}

The obtained values of the investigated physical and chemical factors of piezometric water allowed us to pre-determine the characteristic habitats of the studied species in relation to these factors at each location and in total (Figs 2-5). 

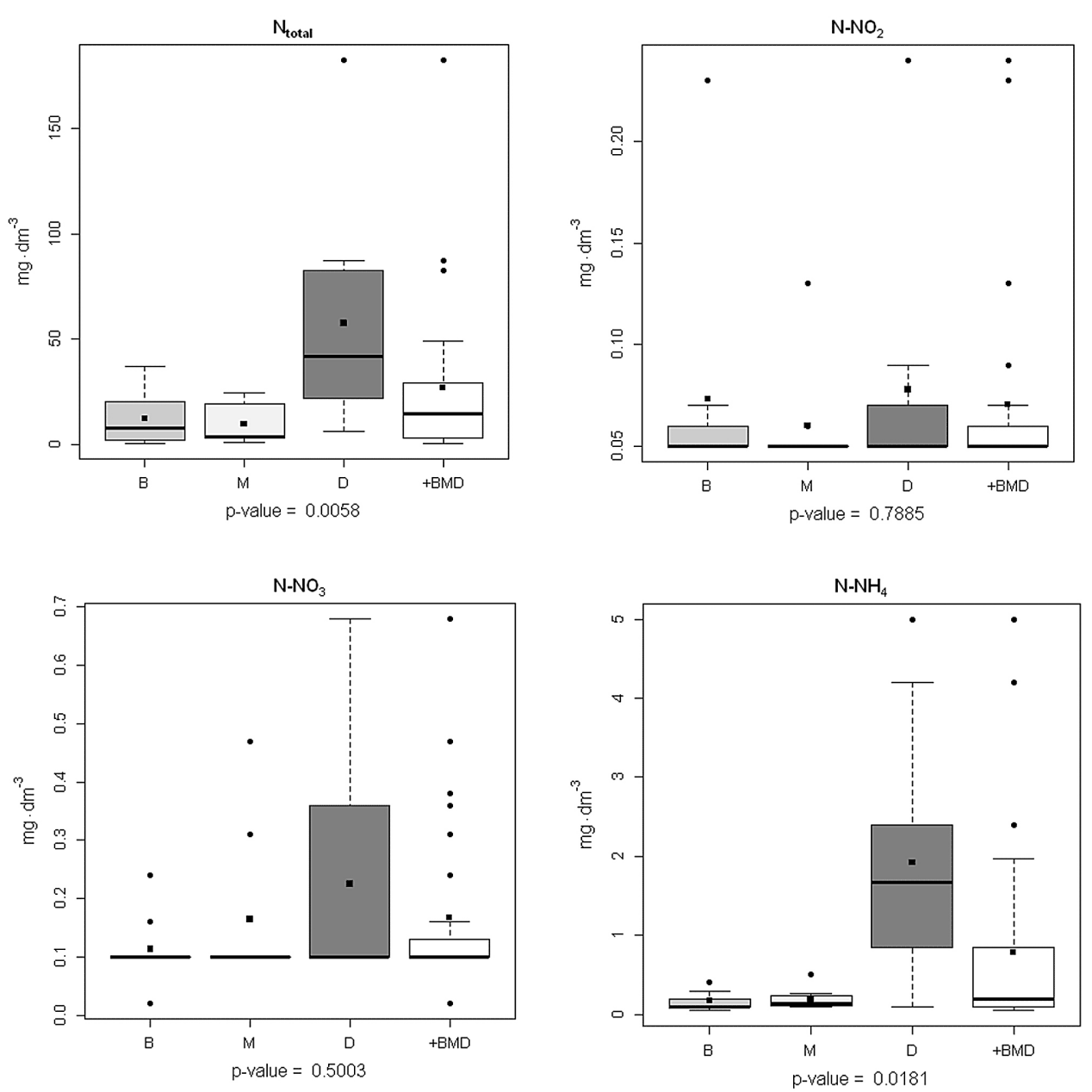

Fig. 2. Distribution of $\mathrm{N}_{\text {total }}, \mathrm{N}-\mathrm{NO}_{2}, \mathrm{~N}-\mathrm{NO}_{3}$ and $\mathrm{N}-\mathrm{NH}_{4}$ values of piezometric groundwater at the study sites in $2011-$ 2013, with statistical analysis and the Kruskal-Wallis test

The ranges of the various factors often diverged to form wide ecological amplitude of tolerance of the studied species. Due to significant deviations of single results, the average values of some parameters $\left(\mathrm{N}-\mathrm{NO}_{2}, \mathrm{~N}-\mathrm{NO}_{3}, \mathrm{~N}-\mathrm{NH}_{4}, \mathrm{P}-\mathrm{PO}_{4}, \mathrm{~S}-\mathrm{SO}_{4}\right.$, and $\mathrm{Na}$ ) were sometimes outside the typical distribution of obser-

vations, giving an ostensible picture of the intensity of a particular feature (Figs 2-5).

In general, the lowest values of the bog water parameters (except for the concentration of $\mathrm{S}^{-\mathrm{SO}_{4}}$ ions, $\mathrm{pH}$ and conductivity) were recorded for the location of the most numerous S. myrtilloides population (Lake
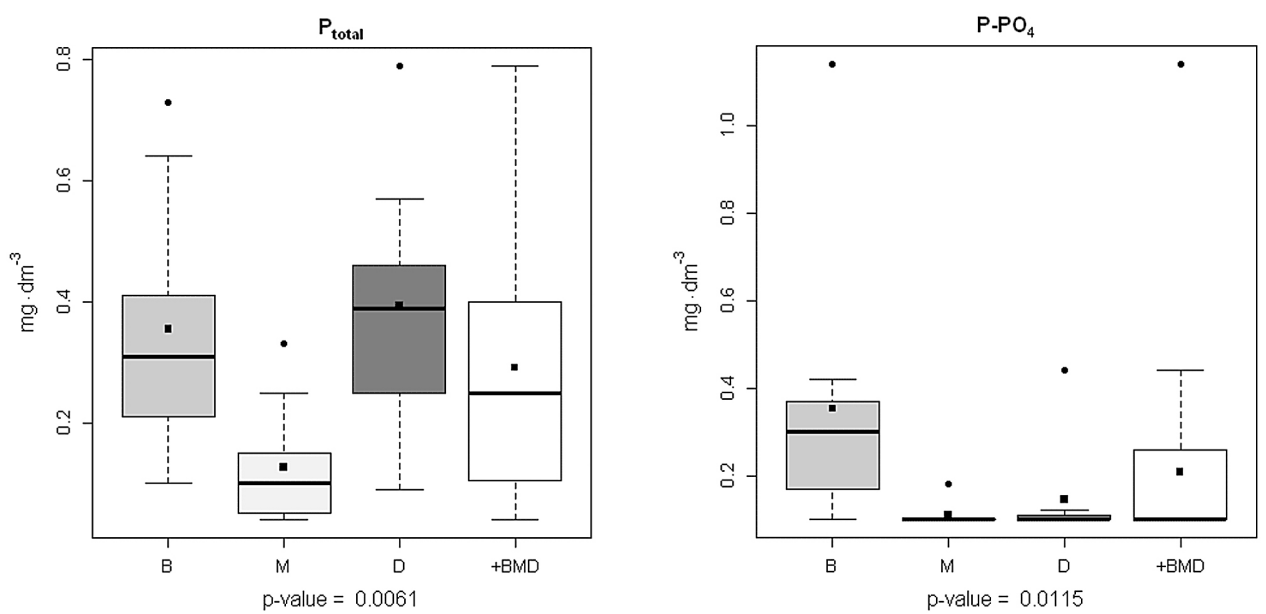

Fig. 3. Distribution of $\mathrm{P}_{\text {total }}$ and $\mathrm{P}-\mathrm{PO}_{4}$ values of piezometric groundwater at the study sites in 2011-2013, with statistical analysis and the Kruskal-Wallis test 

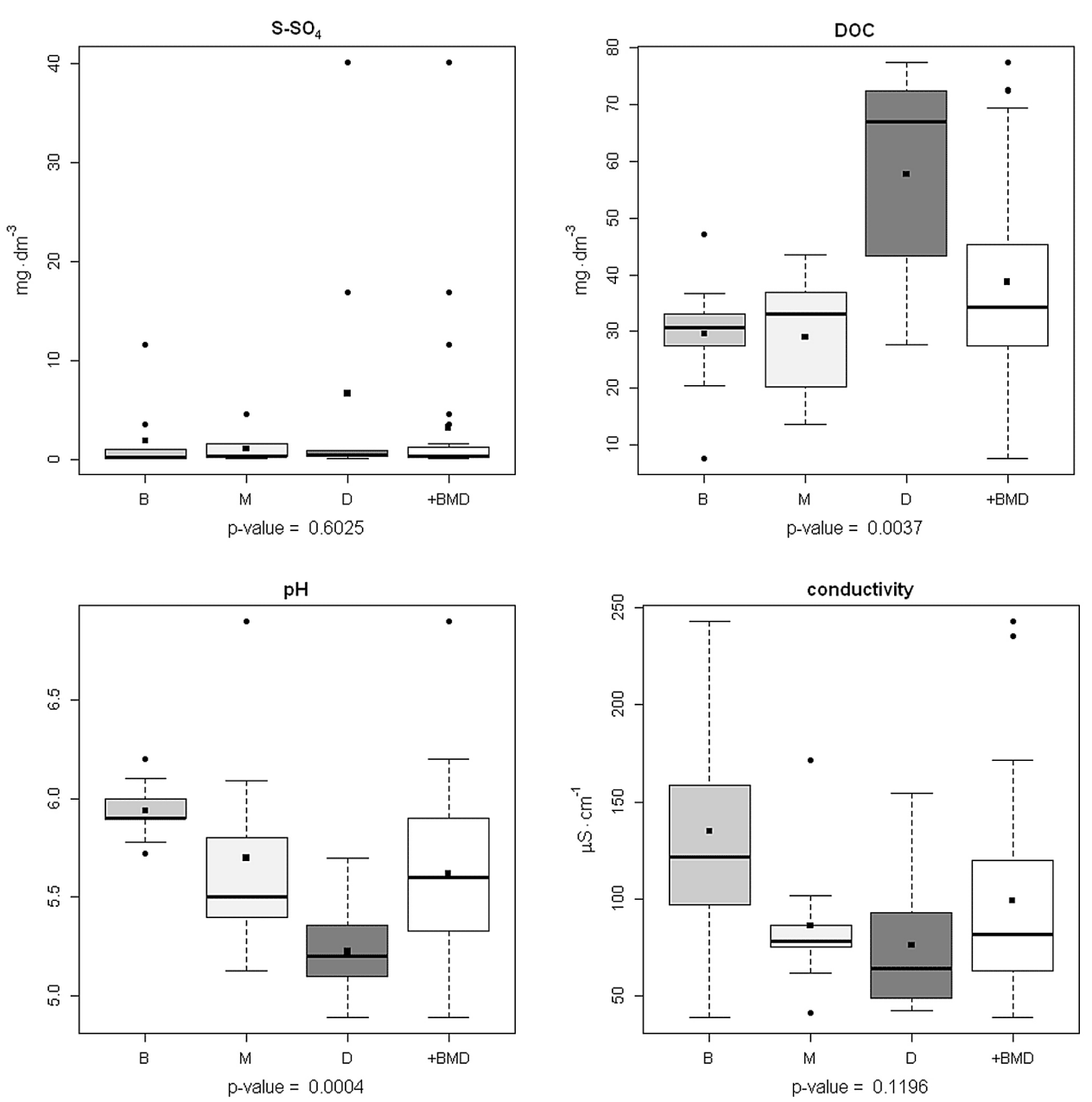

Fig. 4. Distribution of $\mathrm{S}_{-} \mathrm{SO}_{4}$, DOC, $\mathrm{pH}$ and electrolytic conductivity values of piezometric groundwater at the study sites in 2011-2013, with statistical analysis and the Kruskal-Wallis test

Moszne). On the other hand, the site of the least numerous S. myrtilloides population (Lake Bikcze) was characterized by significantly elevated values of some parameters $\left(\mathrm{P}_{-} \mathrm{PO}_{4}, \mathrm{~S}-\mathrm{SO}_{4}, \mathrm{Na}, \mathrm{Ca}, \mathrm{Mg}\right.$, electrolytic conductivity, and $\mathrm{pH}$ ). The water samples collected in a wilderness area known as Dekowina were characterized by higher values of nitrogen fractions, phosphorus and DOC, giving the highest amplitude of these factors (Figs 3-5).

The lowest range of values was reported for the ions of $\mathrm{N}-\mathrm{NO}_{2}, \mathrm{~S}-\mathrm{SO}_{4}$, and $\mathrm{Na}$ in all the locations, whereas the highest range was characterized by significant variation in relation to the parameters and study sites. In the case of the total phosphorus concentration in the water samples from the location on Lake Moszne, the ranges of variation of this factor varied from the ranges of variation for the other locations, likewise for $\mathrm{N}-\mathrm{NH}_{4}, \mathrm{pH}$ and DOC at the Dekowina site as well as for the parameters of $\mathrm{P}_{-} \mathrm{PO}_{4}$, $\mathrm{pH}$ and conductivity at the site on Lake Bikcze (Figs 2-5).

Taking into account all the sites of occurrence of S. myrtilloides in Polesie Podlaskie, $\mathrm{N}-\mathrm{NO}_{2}, \mathrm{NO}_{3}-\mathrm{N}$, $\mathrm{S}_{-} \mathrm{SO}_{4}$ and $\mathrm{Na}$ were characterized by the narrowest average amplitude of the values of the studied physico-chemical factors of the water in the habitats, thus determining probably a positive zone for this species, whereas $\mathrm{P}_{\text {total }}, \mathrm{K}, \mathrm{Ca}, \mathrm{Mg}, \mathrm{DOC}, \mathrm{pH}$ and electrolytic conductivity showed the widest amplitude (Figs 2-5).

The results of the statistical Kruskal-Wallis (K-W) tests, at a $5 \%$ level of significance, for the parameters of $\mathrm{N}-\mathrm{NO}_{2}, \mathrm{~N}-\mathrm{NO}_{3}, \mathrm{~S}-\mathrm{SO}_{4}, \mathrm{~K}, \mathrm{Na}, \mathrm{Ca}, \mathrm{Mg}$ and electrolytic conductivity identified no evidence to reject the null hypothesis of homogeneity of distributions for different locations. Every above-mentioned factor separately showed a similar distribution at the individual study sites. Statistically significant differences were observed for the distributions of the values of $\mathrm{N}_{\text {total }}, \mathrm{N}-\mathrm{NH}_{4}, \mathrm{P}_{\text {total }}, \mathrm{P}-\mathrm{PO}_{4}, \mathrm{pH}$ and DOC, which means a variation in the distributions of the factors at the individual study sites and the rejection of the null hypothesis (Figs 2-5).

The Bonferroni-corrected Mann-Whitney test, as implemented in the base $\mathrm{R}$ function pairwise. wilcox.test, was carried out as post-hoc analysis. A two-tailed p-value of less than 0.05 was considered significant. Statistically significant differences 

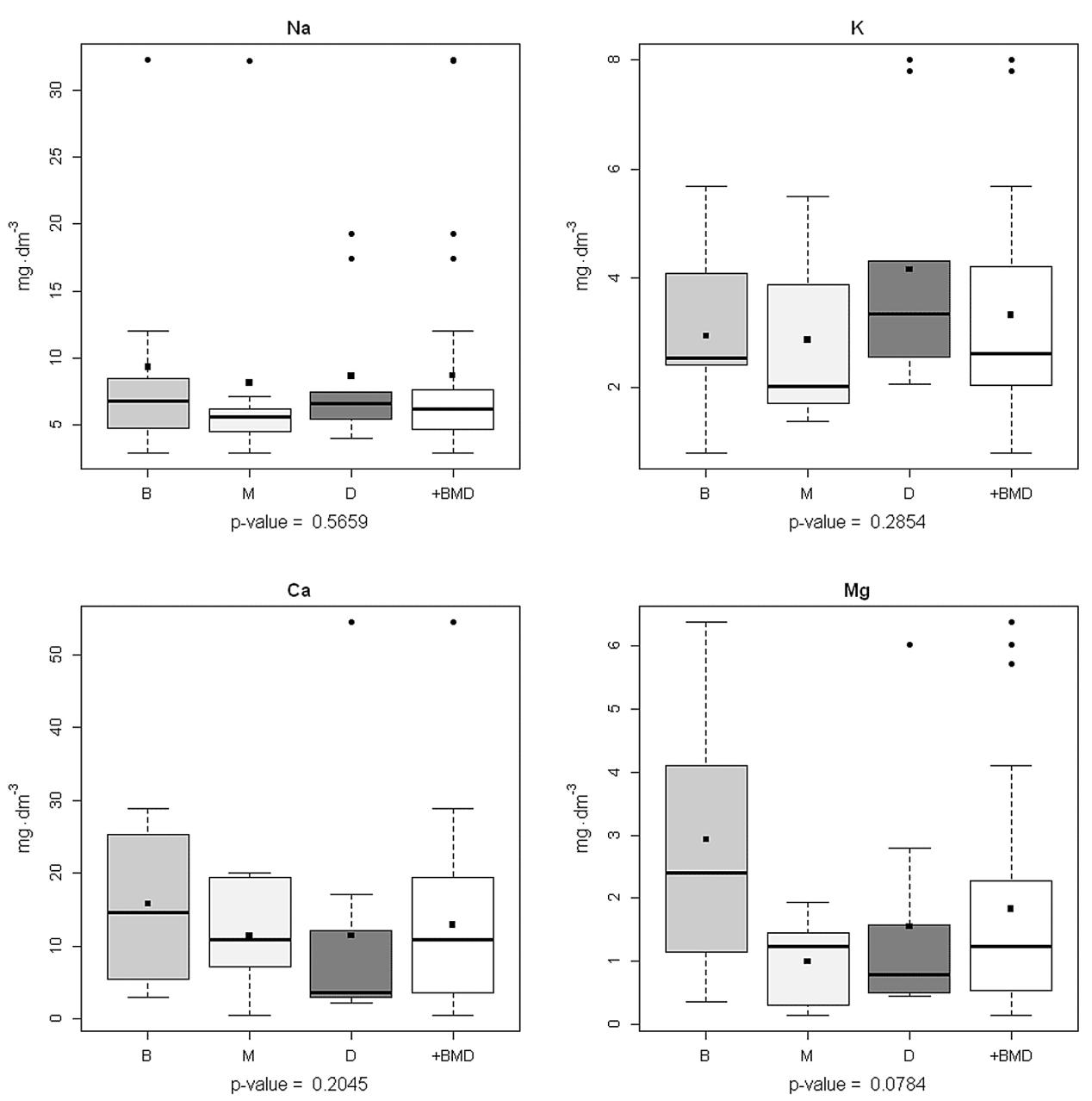

Fig. 5. Distribution of Na, K, Ca and Mg values of piezometric groundwater at the study sites in 2011-2013, with statistical analysis and the Kruskal-Wallis test

were detected by the following comparisons: $\mathrm{N}-\mathrm{NH}_{4}$ : $\mathrm{B}-\mathrm{D}$ (p-value $=.035) ; \mathrm{N}_{\text {total }}: \mathrm{B}-\mathrm{D}(.024), \mathrm{M}-\mathrm{D}(.008)$; $\mathrm{P}_{\text {total }}: \mathrm{B}-\mathrm{M}$ (.031), M-D (.016); P-PO $:$ B-M (.024); DOC: B-D (.008), M-D (.008); pH: B-D (.001), M-D (.035)

The data set was next subjected to DCA, as implemented in the decorana function, which showed a first-axis gradient length of 1.212 in standard deviation units. Therefore, PCA was undertaken by applying the rda function in the vegan package.

Two principal components were extracted which account for $91.31 \%$ of the total variation. The 14 -dimensional samples were projected down onto the orthogonal components to obtain a low dimensional summary of the data (Fig. 6).

According to the post-hoc tests, Dekowina presented significantly higher scores in relation to Moszne concerning $\mathrm{N}_{\text {total }}$ and DOC, and significantly higher scores in relation to Bikcze regarding $\mathrm{N}_{\text {total }}$, $\mathrm{N}-\mathrm{NH}_{4}$ and DOC. Additionally, Dekowina presented significantly lower $\mathrm{pH}$ scores than each of all the other locations.

Furthermore, the post-hoc analysis demonstrated that the $\mathrm{P}_{\text {total }}$ scores were significantly lower in Mo- szne in comparison with Bikcze and Dekowina, while Moszne was found to have significantly lower values of $\mathrm{P}_{-} \mathrm{PO}_{4}$ than those for Bikcze.

PCA identified three key underlying factors: $\mathrm{N}_{\text {to- }}$ tal, electrolytic conductivity, and DOC. In particular, electrolytic conductivity appears to be the main contributor to the first component, while DOC and $\mathrm{N}_{\text {total }}$ are the major contributors to the second one. As part of PCA, we obtained information that the first two principal components have negative coefficients with the three variables. It is worth noting that the first and second principal components are highly correlated with electrolytic conductivity $(r=-.994)$ and $\mathrm{N}_{\text {total }}(\mathrm{r}=-.970)$, respectively (Fig. 6).

\section{Discussion}

The influence of habitat quality on the population structure of rare and endangered flora species is one of the basic problems in studies of the subject (Juśkiewicz-Swaczyna and Choszcz 2012; Skrajna et al. 2012). The relationships between habitat and the condition of flora were analyzed taking into account, 


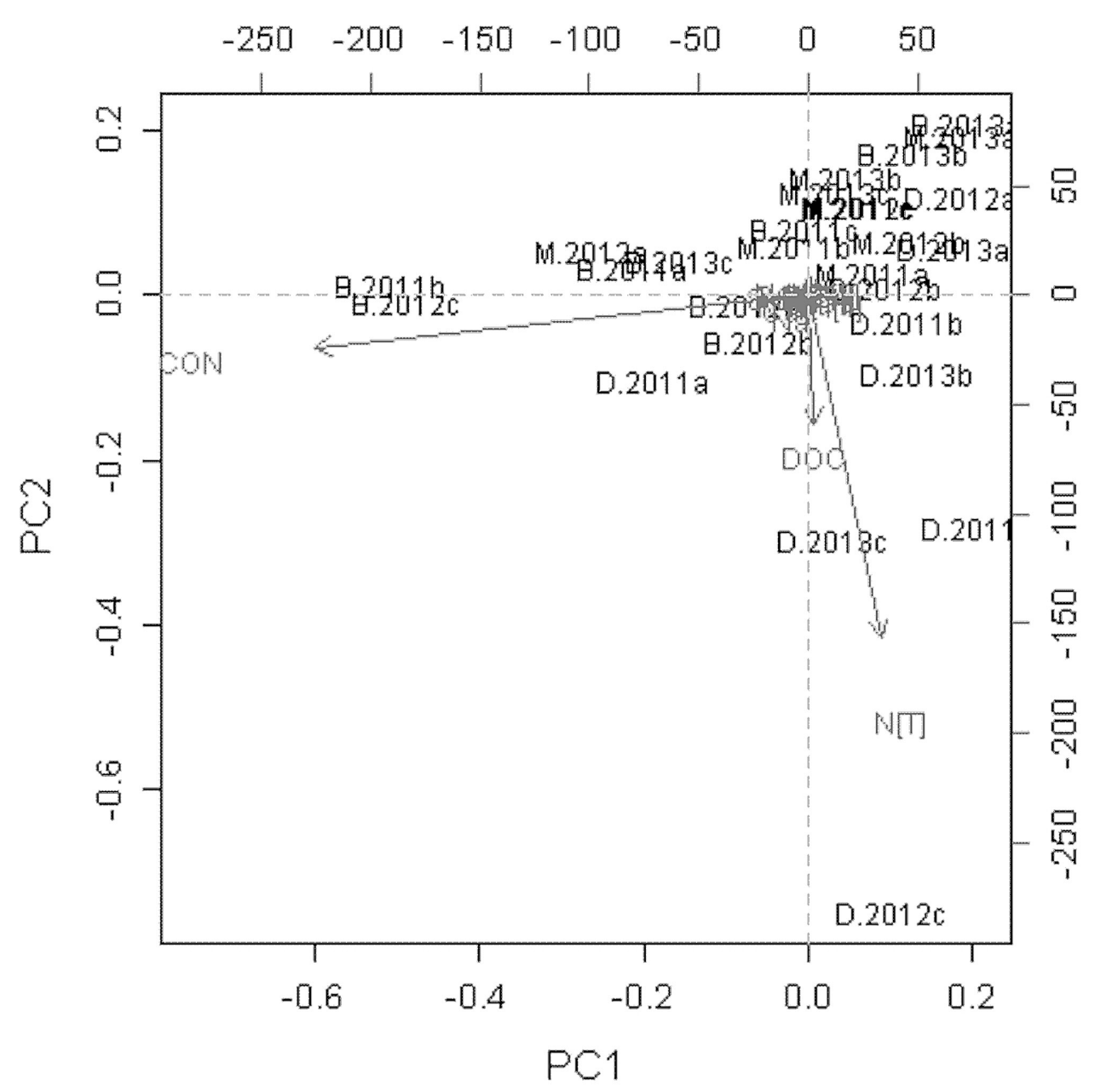

Fig. 6. Projection of the original 14-dimensional scores onto the first two principal components. The black labels indicate individual data items. Each variable (factor) is represented as a vector, while the direction and the length of the vector indicate how the corresponding variable contributes to a principal component

e.g., the heterogeneity of habitats and their effects on species richness, the impact of anthropogenic habitat fragmentation on the numbers and condition of rare plant species (Soomers et al. 2013), and the susceptibility to extinction of small isolated populations (Matthies et al. 2004).

Ecological studies of rare and protected plant taxa, which play a significant role in the functioning of ecosystems in spite of their low proportion in phytocenoses (Lyons et al. 2005), are complemented by hydrochemical habitat analysis.

The data in the Red List of endangered plants in Poland show that out of 418 vascular plant species threatened with extinction 55 (13\%) are bog plants, including Pleistocene subarctic relicts (Zarzycki and Szeląg 1992).

In spite of their anatomical and physiological adaptations to living in harsh conditions, plants are not able to compensate the changes in habitat conditions, often generated directly and indirectly by human activities.

Climatic fluctuations largely determined by human activities are the most important factors degrad- ing the natural ecological systems of peatlands. They result in disturbances in the hydrological regime and in the landscape surrounding a peat bog, also contributing to the changes in the rate of biogenic accumulation and to water level fluctuations, which is clearly related to the functioning of a peat bog (Pogorzelec 2008).

Acid rain, the introduction of toxic and hazardous substances, the eutrophication of oligotrophic habitats due to intensive agricultural production and forestry, and to a lesser extent transport, urban development and tourism as well as other manifestations of anthropopressure all result in the degradation and fragmentation of the habitats of many rare species of plants (Geertsema et al. 2002; Soomers et al. 2013), including directly in peat bogs or their surroundings (Ilnicki 2002).

However, the most important anthropogenic threat to the existence and functioning of peatlands is the lowering of the groundwater level and the introduction of foreign water to an ecological system (Guz 1996; Fijałkowski and Urban 1997). 
Drainage of a peat deposit leads to its settlement, interruption of upward water movement at the interface of the organic and mineral layers, the penetration of oxygen, and consequently to the mineralization of organic matter. In this way, as a result of the increased amplitude of groundwater level fluctuations, the process of organic matter decay is initiated, leading to changes in habitat conditions which affect the qualitative changes in peatland vegetation. The introduction of waters with different physical and chemical characteristics, especially eutrophic ones, has a similar effect. As a result of these effects on a peat ecosystem, the original plant associations are replaced by foreign ones with a different floristic composition or secondary clusters without the peat-forming ability are created. Tall-growing tree and shrub species with high competitive capacity enter the peat bog, for example Betula pendula, Betula pubescens, Salix pentandra, Salix cinerea, or Salix aurita. With a large surface area of their assimilatory organs, their evapotranspiration is significant, resulting in even greater drainage of the peatlands and thus the acceleration of the succession development of biota. A consequence of such transformations is the loss of locations of less competitive bog species with reduced adaptive capacity, often including valuable protected flora species which are Pleistocene boreal relicts (Pogorzelec 2008).

Similar anthropogenic changes disturbing the habitat conditions of aquatic and peat ecosystems also relate to Polesie Podlaskie in Eastern Poland (Wilgat 1954).

Various land drainage projects (riverbed training, digging drainage ditches, the inclusion of the lakes in the runoff network) have affected the changes in hydrological relations in the region since the mid-nineteenth century. Additionally, the construction (19541961) and operation of the Wieprz-Krzna drainage canal, including the conversion of several lakes into water storage reservoirs (e.g. Lake Bikcze), have significantly contributed to an increase in the rate of water runoff, the elimination of surface stagnation, and a reduction in natural water retention, which has resulted in a decrease in the water table by $50-80 \mathrm{~cm}$ on average. The Wieprz-Krzna Canal carries water with different physical and chemical characteristics than the water typical of this region, which further contributes to the changes in habitat conditions of the peatland ecosystems. Similarly, the activities of the Lublin Coal Basin may have an indirect impact on the hydrological status of the region through hydraulic relationships of a part of mining deposits (Michalczyk et al. 1995).

The changes in hydrological relations of Polesie Podlaskie are reflected in the transformations of habitat conditions in the aquatic ecosystems and peat bogs of this region, often going beyond the compen- satory capacity of many valuable plant species, such as Pleistocene boreal relicts.

Despite the scanty literature data on S. myrtilloides as a boreal relict fully protected in Poland, it should be noted that it is characterized by a quite wide positive zone with respect to many environmental factors. However, in Poland the number of its locations and the size of its population have gradually decreased. Until the 1970s, it occurred in about 90 sites on the Lower Vistula River, in the Masurian and Łęczna-Włodawa Lake Districts, in the Roztocze region, and less frequently on the edges of the Kampinos Forest, Silesian Lowland and Orava as well as on the Brda River (Kępczyński and Rutkowski 1985). Most of these locations no longer exist (Churski and Danielewicz 2008). In the Polesie Podlaskie area, the occurrence of $S$. myrtilloides at numerous sites associated with the peat bogs around the following lakes: Białe Sosnowickie, Brudno, Czarne Gościnieckie, Długie, Moszne, Kosaciec and Pilno, was described in the late 1950's (Fijałkowski 1959). As regards these locations, the occurrence of impoverished populations of this species near the lakes Orchów, Dubeczyńskie and Brudno (Urban and Wawer 2001), on the lakes Bikcze and Moszne (Pogorzelec and Banach 2008) as well as in the Dekowina wilderness area was only confirmed. It is probably associated with a change in habitat conditions leading to the acceleration of ecological succession in the habitat ecosystems where this species occurs.

In 2011-2013, however, the habitat conditions related to the specific characteristics of the peatland piezometric water in the investigated sites of occurrence of swamp willow were characterized by neither significant amplitudes nor significant differences between sites, which was confirmed by the statistical analysis (K-W tests). Perhaps this is why in the course of the study there were no changes in the number of individuals in these populations, though compared to the period 2007-2008 the number of $S$. myrtilloides individuals had decreased more than 14fold in one of the locations (Lake Bikcze) (data not published).

The location in which this species was represented in greatest numbers (Lake Moszne) was characterized by the lowest values in the case of most of the parameters, so it can be considered to be the most optimal set of conditions conducive to maintaining the population of Salix myrtilloides in various habitats. In the case of nitrogen fractions, similar values were recorded for the locations with the least numerous (Lake Bikcze) and most numerous populations of $S$. myrtilloides and therefore they need not be a significant limiting factor. The post hoc analysis also suggest that the higher values of $\mathrm{pH}$, electrolytic conductivity, $\mathrm{Na}, \mathrm{Ca}$, and $\mathrm{Mg}$ found in the shrinking location of swamp willow on Lake Bikcze can however be un- 
favorable for the continued persistence of the studied populations of this species.

The principal component analysis revealed that the following parameters: electrical conductivity, $\mathrm{N}_{\text {to- }}$ tal and DOC, predominantly affected the variation of the other habitat factors, but at the same time this analysis found that there was a low correlation between electrolytic conductivity and the above-mentioned factors.

The lack of significant differences in the studied factors of peatland piezometric water at the sites with different numbers of the Salix myrtilloides population requires the identification of other limiting factors for this species in Polesie Podlaskie and the introduction of programs for active conservation of this species.

The obtained results and discussion allowed us to formulate the following conclusions:

1. The amplitude of the values of the physico-chemical factors of groundwater at different locations of S. myrtilloides is probably evidence of a wide range of ecological tolerance of the studied species in relation to these factors.

2. The distribution of the values of a part of the habitat parameters analyzed was probably favorable for the maintenance of the populations, while the distribution of the other ones should be considered as neutral or unfavorable.

3. Some of the habitat factors were characterized by a similar distribution of values for the locations with different numbers of the S. myrtilloides population and therefore they were not significant limiting factors.

4. The maintenance of the Salix myrtilloides population in Eastern Poland requires further comprehensive studies of its habitat conditions and the introduction of programs for active protection of this species.

\section{Acknowledgments}

The study was supported by the research grant NN 304385239 from Poland's Ministry of Science and Higher Education.

\section{References}

Churski M., Danielewicz W. 2008. Salix myrtilloides in the north central Poland. Distribution, threats and conservation. Dendrobiology 60: 3-9.

Fijałkowski D. 1959. Szata roślinna jezior łęczyńsko-włodawskich i przylegających do nich torfowisk. Annales UMCS. Sectio B, 14: 131-206.

Fijałkowski D. 1991. Zespoły roślinne Lubelszczyzny. Wydawnictwo Uniwersytetu Marii Curie-Skłodowskiej, Lublin.
Fijałkowski D., Urban D. 1997. Szata roślinna obiektu wodno-torfowiskowego „Uściwierzek” i jej przekształcenia. Annales UMCS, Sectio C. 52: 119-143.

Geertsema W., Opdam P., Kropff M.J. 2002. Plant strategies and agricultural landscapes: survival in spatially and temporally fragmented habitat. Landscape Ecology 17: 263-279.

Guz T. 1996. Ekologiczna rola mokradeł w środowisku przyrodniczym Lubelszczyzny. Ekoinżynieria 1: 21-25.

Ilnicki P. 2002. Torfowiska i torf. Wydawnictwo Akademii Rolniczej im. Augusta Cieszkowskiego, Poznań.

Juśkiewicz-Swaczyna B., Choszcz D. 2012. Effect of habitat quality on the structure of populations of Pulsatilla patens (L) Mill. (Ranunculaceae) - rare and endangered species in European flora. Polish Journal of Ecology 60: 567-576.

Kępczyński K., Rutkowski L. 1985. Roślinność torfowiska $z$ Salix myrtilloides L. koło Rakowca w województwie elbląskim. Acta Universitatis Nicolai Copernici, Nauki Matematyczno-Przyrodnicze 27: 3-16.

Kłosowski G., Kłosowski S. 2001. Flora Polski. Rośliny wodne i bagienne. Wydawnictwo MULTICO, Warszawa.

Kruszelnicki J., Gostyńska-Jakuszewska M., Rutkowski L. 2001. Salix lapponum L. (wierzba lapońska). In: Polska Czerwona Księga Roślin. Paprotniki i rośliny kwiatowe. Kaźmierczakowa R., Zarzycki K. (eds.). Instytut Botaniki PAN, Kraków, pp. 71-73.

Lyons K.G., Brigham C.A., Traut B.H., Schwartz M.W. 2005. Rare species and ecosystem functioning. Conservation Biology 19: 1019-1024.

Matthies D., Bräuer I., Maibom W., Tscharntke T. 2004. Population size and the risk of local extinction: empirical evidence from rare plants. Oikos 105: 481-488.

Michalczyk Z., Bartoszewski S., Głowacki S., Turczyński M. 1995. The Water Relations Profile of Poleski National Park and its Buffer Area. In: The Water Ecosystems Protection in Poleski National Park. Radwan S. (ed.). Wyd. TWWP, Lublin, pp. 11-24.

Mirek Z., Zarzycki K., Wojewoda W., Szeląg Z. 2006. Czerwona lista roślin i grzybów Polski. Instytut Botaniki PAN im. W. Szafera, Kraków.

Oksanen J., Blanchet F.G., Kindt R., Legendre P., Minchin P.R., O'Hara R.B., Simpson G.L., Solymos P., Stevens M.H.H., Wagner H. 2013. vegan: Community Ecology Package. R package version 2.0-8. http://CRAN.R-project.org/package = vegan. 
Piękoś-Mirkowa H. 2003. Flora Polski. Atlas roślin chronionych. MULTICO Oficyna Wydawnicza, Warszawa.

Pogorzelec M. 2008. Influence of chosen environmental abiotic factors on Salix lapponum L. populations in Polesie Lubelskie Region. Polish Journal of Environmental Studies 17: 581-586.

Pogorzelec M. 2009. Downy willow (Salix lapponum L.) as a component of different phytocoenoses in Polesie National Park. Acta Agrobotanica 62: 107-116.

Pogorzelec M., Banach B. 2008. The occurrence of rare and protected plant species on the peat bog near Lake Bikcze (Łęczyńsko-Włodawskie Lakeland). Acta Agrobotanica 61: 113-120.

R Core Team. 2013. R: A language and environment for statistical computing. R Foundation for Statistical Computing, Vienna, Austria. http://www.R-project.org/.

Serafin A. 2009. Phytoplankton productivity in littoral adjacent to peat-bog in two limnologically distinct lakes (Łeczyńsko-Włodawskie Lake District). Ecohydrology and Hydrobiology 9: 201207.

Serafin A., Pogorzelec M. 2011. Changes in the flora of the eastern and southern shore area of lake Pia- seczno in the years 2003-2010. Acta Agrobotanica 64: 141-150.

Skrajna T. Kubicka H., Rzymowska Z. 2012. Illecebrum verticillatum L. - endangered species in agrocenoses of eastern Poland: assessment of ecological and genetic indicators for protection goals. Polish Journal of Ecology 60: 577-589.

Soomers H., Karssenberg D., Verhoeven J.T.A., Verweij P.A., Wassen M.J. 2013. The effect of habitat fragmentation and abiotic factors on fen plant occurrence. Biodiversity and Conservation 22: 405-424.

Tobolski K. 2003. Torfowiska na przykładzie Ziemi Świeckiej. Wyd. Towarzystwo Przyjaciół Dolnej Wisły, Toruń.

Urban D., Wawer M. 2001. Salix lapponum L. i S. myrtilloides L. w okolicach Sobiboru na Pojezierzu Łeczynsko-Włodawskim. Annales UMCS. Agricultura, Sectio E, 56: 83-93.

Wilgat T. 1954. Jeziora Łęczyńsko-Włodawskie. Annales UMCS. Sectio B, 8: 37-122.

Zarzycki K., Szeląg Z. 1992. Lista roślin zagrożonych w Polsce. Instytut Botaniki PAN im W. Szafera, Kraków. 